\section{Microbiological profile of culture- proven cases of exogenous and endogenous endophthalmitis: a 10-year retrospective study}

R Ramakrishnan'1, MJ Bharathi ${ }^{2}$, C Shivkumar ${ }^{3}$, S Mittal ${ }^{4}$, R Meenakshi ${ }^{4}$, MA Khadeer ${ }^{1}$ and A Avasthi ${ }^{5}$

\begin{abstract}
Purpose To identify the microbial aetiology of infectious endophthalmitis and to determine the in vitro antibacterial susceptibilities of bacterial isolates. Methods A retrospective analysis was carried out of all patients presenting between January 1997 and December 2006 with clinically diagnosed infectious endophthalmitis who underwent microbiological evaluation. Intraocular specimens (aqueous and vitreous fluids) were collected from all cases of clinically suspected infectious endophthalmitis. In addition to intraocular aspirates, blood specimens from endogenous endophthalmitis, and corneal and scleral scrapes from relevant cases were also collected. The collected intraocular specimens, blood specimens, and corneal and scleral scrapes were subjected to microbiological evaluation.

Results Samples from 955 patients with endophthalmitis underwent microbiological analysis, of which $424(44.4 \%)$ were found to be culture positive. Of $424,364(85.8 \%)$ had bacterial growth and the remaining $60(14.2 \%)$ had fungal growth. Among post-surgical endophthalmitis, Gram-negative bacilli $(75 \%)$ were found to be the predominant cause for developing fulminant onset, Staphylococcus spp. (68.6\%) for acute, and Streptococcus spp. $\mathbf{7 5 \% )}$ for chronic onset of infections, whereas in post-traumatic endophthalmitis, Gramnegative bacilli $(65.2 \%)$ were found to be the predominant cause for fulminant onset, Gram-positive bacillus (28.4\%) for acute onset, and fungi $(52.3 \%)$ for chronic onset of
\end{abstract}

infections. Endophthalmitis associated with microbial keratitis was mainly caused by filamentous fungi (37.2\%) and Gram-negative bacilli (37.2\%). Overall, gatifloxacin $(\mathbf{9 7 . 7 \%})$ showed highest activity against bacterial isolates followed by ciprofloxacin (95.9\%) and ofloxacin (95.1\%).

Conclusion Gram-negative bacilli cause predominantly fulminant onset, Staphylococci and Gram-positive bacilli acute, and Streptococci, Nocardia, and fungi chronic endophthalmitis. Gatifloxacin demonstrated greatest efficacy against these bacterial isolates. Eye (2009) 23, 945-956; doi:10.1038/eye.2008.197; published online 4 July 2008

Keywords: post-operative endophthalmitis; post-traumatic endophthalmitis; endophthalmitis associated with microbial keratitis; endophthalmitis with scleritis; microbial pathogens; antibacterial susceptibilities

\section{Introduction}

Infectious endophthalmitis, a potentially blinding disorder, is a major public health concern. Infectious endophthalmitis is defined as an inflammation of intraocular tissues or fluids secondary to intraocular infection. ${ }^{1}$ Colonization of organisms inside the eye can occur either by the introduction of infectious agents into the eye following a breach in the ocular barriers or by dissemination through the systemic blood stream. When infectious agents reach the vitreous cavity across an opening in
${ }^{1}$ Centre for Excellence in Glaucoma, Aravind Eye Hospital \& Postgraduate Institute of Ophthalmology, Tirunelveli, Tamil Nadu, South India

${ }^{2}$ Microbiology Research Centre, Aravind Eye Hospita \& Postgraduate Institute of Ophthalmology, Tirunelveli, Tamil Nadu, South India

${ }^{3}$ Cataract and General Ophthalmology, Aravind Eye Hospital \& Postgraduate Institute of Ophthalmology, Tirunelveli, Tamil Nadu, South India

${ }^{4}$ Cornea and Refractive Surgery, Aravind Eye Hospital \& Postgraduate Institute of Ophthalmology, Tirunelveli, Tamil Nadu, South India

${ }^{5}$ Retina Service, Aravind Eye Hospital \& Postgraduate Institute of Ophthalmology, Tirunelveli, Tamil Nadu, South India

Correspondence: MJ Bharathi, Microbiology Research Centre, Aravind Eye Hospital \& Postgraduate Institute of Ophthalmology, Tirunelveli, Tamil Nadu,

South India

Tel: + 91-0462-2337103; Fax: + 91-0462-2331633.

E-mail: jayahar@

tvl.aravind.org

Received: 27 October 2007 Accepted in revised form: 31 May 2008 Published online: 4 July 2008 
the globe, it is termed as exogenous endophthalmitis and when it occurs by hematogenous spread, it is termed as endogenous or metastatic endophthalmitis. Exogenous endophthalmitis occurs usually following surgical or traumatic alteration of the structural integrity of the globe. Occasionally, exogenous endophthalmitis results from contagious spread of infectious microbes from the ocular adnexa, especially following infections on the cornea or sclera. ${ }^{2}$

Post-operative infectious endophthalmitis can be encountered after any intraocular procedure, and its incidence is estimated as $0.05-0.37 \%$. The incidence can vary with the surgical procedure and is most frequently seen with cataract surgery where coagulase-negative staphylococci (CoNS) are isolated in nearly $70 \%$ of cases. ${ }^{3,4}$ Exogenous endophthalmitis is more common following penetrating ocular injuries than following surgery, and the reported incidence among penetrating injury ranges between 3 and 17\%. ${ }^{4}$ Endogenous endophthalmitis (EE) is less common than exogenous endophthalmitis and accounts for only 2-6\% of all cases of endophthalmitis, usually in debilitated or immuno-compromised patients or in patients with a history of intravenous drug abuse. ${ }^{5}$

Literature reviews show a distinct pattern of variation in the microbial aetiology of infectious endophthalmitis according to the clinical settings. ${ }^{2-8}$ The microorganisms responsible for post-operative endophthalmitis (eg staphylococci and streptococci) generally reside on the eyelid margins and pre-ocular tear film, whereas in the case of post-traumatic infectious endophthalmitis (eg Bacillus spp. and fungi), the organisms are generally derived from the environment. The most common causes of EE are Streptococcus species, Staphylococcus species, and Bacillus cereus. ${ }^{9,10}$ Hence, documentation of the microbial pathogens causing endophthalmitis is of the highest priority and their antimicrobial susceptibilities are essential for better understanding and prompt management of this disease.

Several studies have investigated risk factors, microbial aetiology, visual outcomes, and the causative role of residential microbial flora in developing endophthalmitis. ${ }^{11-13}$ However, none of the single centre series has described the comparison of the spectrum of microbial pathogens causing post-operative, posttraumatic, and post-corneal infective and EE. The purpose of this study was to determine specific microbial pathogens responsible for the development of the various forms of endophthalmitis presenting in a tertiary eye care referral centre in South India. An attempt was also made to compare the in vitro antibacterial susceptibility pattern of bacterial pathogens recovered from each type of endophthalmitis. This will help significantly in the implications on the treatment protocol practised in such patients.

\section{Materials and methods}

A retrospective analysis was performed of all case records with culture-proven endophthalmitis treated at Aravind Eye Hospital and Postgraduate Institute of Ophthalmology, Tirunelveli, Tamil Nadu, South India over 10 years from January 1997 to December 2006. As a standard protocol followed in our institute, the diagnosis of endophthalmitis was based on the presence of pain, inflammation including anterior chamber cellular reaction and flare and vitreous cells or exudates, decrease in visual acuity and loss of media clarity with or without the presence of hypopyon following intraocular surgery, penetrating injury and/or corneal or scleral infections. ${ }^{1,14-16}$ All patients with endophthalmitis presenting to our referral centre undergo thorough evaluation that includes: (1) the documentation of the demographic features, duration of symptoms, interval between the event and presentation to this institution, and use of medications; (2) information pertaining to the predisposing factors: ocular surgery, history of trauma, associated ocular diseases, systemic conditions, and presence of systemic diseases; (3) ocular examination findings (presenting Snellen's visual acuity, presence of hypopyon, presence of vitreous cells, and optic disc visibility), ultrasonography (with attention to the presence of vitreous membranes and vitreous exudates); and (4) microbiological workup that includes direct microscopy and culture results with antibacterial susceptibilities. Endophthalmitis occurring within 4 days of surgery or trauma were categorized as fulminant onset endophthalmitis; infections that present less than 6 weeks after surgery or trauma were categorized as acute endophthalmitis, whereas infection that develop 6 weeks after the initial event were categorized as chronic endophthalmitis. ${ }^{2}$

The confirmatory diagnosis of infectious endophthalmitis was established by the demonstration of significant microbial growth in cultures of intraocular specimens and in cases of EE, along with intraocular specimen presence of the same infectious agents in cultures of blood. Endophthalmitis due to corneal and scleral infections was confirmed by obtaining the same microbial pathogens in both corneal or scleral scrape and intraocular aspirates. The microbiological diagnosis of endophthalmitis was confirmed by a systematic approach for procuring intraocular fluids. Using standard techniques, ${ }^{14-16} 0.1-0.2 \mathrm{ml}$ of anterior chamber fluids were aspirated through the peripheral clear corneal paracentesis using a 26-gauge needle on a $1 \mathrm{ml}$ plastic sterile disposable tuberculin syringe. Vitreous specimen $(0.5-1.0 \mathrm{ml})$ was obtained using a 22-gauge needle introduced through the pars plana just before injecting the intra-vitreal antibiotics or performing core 
vitrectomy. The aspirated intraocular fluids were immediately inoculated on blood agar, chocolate agar, Sabouraurd's dextrose agar, brain heart infusion broth, and thioglycollate broth medium for culture in the operating room. Smears were prepared for Gram's and Giemsa staining techniques and also for $10 \%$ potassium hydroxide wet mount preparation. All inoculated media were incubated aerobically. A positive culture was defined as a growth of the same organisms on more than two solid phase mediums or confluent growth on one solid medium. ${ }^{14}$ In general, indications for vitrectomy were according to the Endophthalmitis Vitrectomy Study guidelines. ${ }^{15}$ As the population study consisted of patients and volunteers, an Institutional Review Board was not necessary.

\section{Statistical analysis}

Statistical software, STATA 8.1 (Stata Corporation, College Station, TX, USA) was used for statistical analysis. A statistical analysis was carried out to determine the association between microbial aetiology and clinical settings, and microbial aetiology and type of onset of endophthalmitis. Pearson's $\chi^{2}$ test was used for analysis, and $P$-value $<0.05$ was considered to be statistically significant.

\section{Results}

Table 1 summarizes the culture positivity of the patients with endophthalmitis who underwent microbiological evaluation according to the clinical setting. During the study period of 10 years, a total of 955 patients with endophthalmitis underwent microbiological analysis and a single eye was infected in all cases. Of 955, $424(44.4 \%)$ were found to be culture positive for microbial growth, of which $413(97.4 \%)$ had exogenous endophthalmitis and $11(2.6 \%)$ had EE. The rate of culture positivity was found to be higher among aspirates from exogenous endophthalmitis $(46.7 \% ; 413$ of 884$)$ when compared with EE $(15.5 \% ; 11$ of 71$)(P<0.0001)$. The rate of culture positivity of specimens from eyes with post-surgical endophthalmitis $(36 \% ; 225$ of 625$)$ was found to be significantly lower than those obtained from eyes with endophthalmitis due to trauma $(65 \% ; 141$ of 217$)$ $(P<0.001)$, microbial keratitis $(100 \% ; 43$ of 43$)(P<0.001)$, and microbial scleral abscess $(100 \% ; 4$ of 4$)(P=0.008)$. The rate of culture-proven endophthalmitis was found to be higher among acute onset than chronic onset both in post-surgical $(66.2 \% ; 149$ of 225 , including 28 fulminant onset) and post-traumatic endophthalmitis $(68.8 \%$; 97 of 141, including 23 fulminant onset). The growth patterns of microbes isolated from intraocular aspirates, corneal scrapes, scleral scrapes, and blood specimens collected from patients with culture-proven endophthalmitis, according to the duration of onset, are presented in Table 2.

Microbial pathogens recovered from eyes with infectious endophthalmitis are documented in Table 3. Of the total of 424 patients with culture-proven endophthalmitis, $364(85.8 \%)$ had bacterial aetiology and the remaining $60(14.2 \%)$ had fungal aetiology. Among bacteria, CoNS $(30.5 \%$; 111 of 364$)$ were the predominant isolates followed by Streptococcus pneumoniae $(22.3 \% ; 81$ of 364) and Pseudomonas aeruginosa (11.5\%; 42 of 364), whereas among fungal isolates recovered, Aspergillus spp. $(60 \% ; 36$ of 60$)$ were the most common isolates followed by Fusarium spp. (33.3\%; 20 of 60). Among

Table 1 Patients with endophthalmitis who underwent microbiological evaluation between January 1997 and December 2006 according to the clinical settings

\begin{tabular}{|c|c|c|c|}
\hline Sl no. & Categories of endophthalmitis & $\begin{array}{l}\text { No. of patients/eyes } \\
\text { that underwent } \\
\text { microbiological } \\
\text { evaluation }\end{array}$ & $\begin{array}{c}\text { No. of patients whose intraocular aspirates, } \\
\text { corneal scrapes, scleral scrapes and/or blood } \\
\text { specimens were positive for microbial growth } \\
(\%)\end{array}$ \\
\hline \multirow[t]{5}{*}{1} & Total no. of patients/eyes with exogenous endophthalmitis & 884 & $413(46.7)$ \\
\hline & $\begin{array}{l}\text { (i). No. of patients/eyes with endophthalmitis after } \\
\text { intraocular surgeries }\end{array}$ & 625 & $225(36)$ \\
\hline & $\begin{array}{l}\text { (ii). No. of patients/eyes with endophthalmitis after } \\
\text { penetrating ocular injuries }\end{array}$ & 217 & $141(65)$ \\
\hline & $\begin{array}{l}\text { (iii). No. of patients/eyes with endophthalmitis associated } \\
\text { with microbial keratitis }\end{array}$ & 43 & $43(100)$ \\
\hline & $\begin{array}{l}\text { (iv). No. of patients/eyes with endophthalmitis associated } \\
\text { with microbial scleral abscess }\end{array}$ & 4 & $4(100)$ \\
\hline \multirow[t]{2}{*}{2} & $\begin{array}{l}\text { Total no. of patients/eyes with endogenous } \\
\text { endophthalmitis }\end{array}$ & 71 & $11(15.5)$ \\
\hline & Total no. of patients/eyes (\%) & 955 & $424(44.4)$ \\
\hline
\end{tabular}


Table 2 Microbial growth pattern of intraocular aspirates, corneal scrapes, scleral scrapes, and blood specimens collected from patients with infectious endophthalmitis presenting at a tertiary eye care referral centre in South India between January 1997 and December 2006

\begin{tabular}{|c|c|c|c|c|c|c|c|c|c|c|c|c|c|c|c|}
\hline \multirow{3}{*}{$\begin{array}{l}\text { Name of the } \\
\text { specimens } \\
\text { collected from } \\
\text { patients with } \\
\text { endophthalmitis }\end{array}$} & \multirow{3}{*}{$\begin{array}{l}\text { Total no. of } \\
\text { eyes with } \\
\text { endophthalmitis } \\
\text { positive for } \\
\text { microbial } \\
\text { growth }\end{array}$} & \multicolumn{14}{|c|}{ No. of eyes with exogenous endophthalmitis positive for microbial growth } \\
\hline & & \multicolumn{4}{|c|}{$\begin{array}{l}\text { Eyes with endophthalmitis after intraocular } \\
\text { surgeries positive for microbial growth }\end{array}$} & \multicolumn{4}{|c|}{$\begin{array}{l}\text { Eyes with endophthalmitis after } \\
\text { penetrating ocular injuries positive for } \\
\text { microbial growth }\end{array}$} & \multicolumn{2}{|c|}{$\begin{array}{c}\text { Endophthalmitis } \\
\text { associated with } \\
\text { microbial keratitis } \\
\text { positive for microbial } \\
\text { growth }\end{array}$} & \multicolumn{2}{|c|}{$\begin{array}{l}\text { Endophthalmitis } \\
\text { associated with } \\
\text { scleral abscess } \\
\text { positive for } \\
\text { microbial growth }\end{array}$} & \multicolumn{2}{|c|}{$\begin{array}{l}\text { No. of eyes with } \\
\text { endogenous } \\
\text { endophthalmitis } \\
\text { positive for } \\
\text { microbial growth }\end{array}$} \\
\hline & & $\begin{array}{c}\text { Total } \\
\text { no. }(\%)\end{array}$ & $\begin{array}{l}\text { No. of } \\
\text { eyes with } \\
\text { fulminant } \\
\text { type of } \\
\text { endo- } \\
\text { phthalmitis: } \\
<4 \text { days }\end{array}$ & $\begin{array}{l}\text { No. of eyes } \\
\text { with acute } \\
\text { type of } \\
\text { endo- } \\
\text { phthalmitis: } \\
4 \text { days-6 } \\
\text { weeks }\end{array}$ & $\begin{array}{l}\text { No. of eyes } \\
\text { with chronic } \\
\text { type of } \\
\text { endo- } \\
\text { phthalmitis: } \\
>6 \text { weeks }\end{array}$ & $\begin{array}{c}\text { Total } \\
\text { no. }(\%)\end{array}$ & $\begin{array}{l}\text { No. of } \\
\text { eyes with } \\
\text { fulminant } \\
\text { type of } \\
\text { endo- } \\
\text { phthalmitis: } \\
<4 \text { days }\end{array}$ & $\begin{array}{l}\text { No. of eyes } \\
\text { with acute } \\
\text { type of } \\
\text { endo- } \\
\text { phthalmitis: } \\
4 \text { days-6 weeks }\end{array}$ & $\begin{array}{l}\text { No. of eyes } \\
\text { with chronic } \\
\text { type of } \\
\text { endo- } \\
\text { phthalmitis: } \\
>6 \text { weeks }\end{array}$ & $\begin{array}{c}\text { Total } \\
\text { no. }(\%)\end{array}$ & $\begin{array}{l}\text { No. of eyes } \\
\text { with chronic } \\
\text { type of } \\
\text { endo- } \\
\text { phthalmitis: } \\
>6 \text { weeks }\end{array}$ & $\begin{array}{c}\text { Total } \\
\text { no. (\%) }\end{array}$ & $\begin{array}{l}\text { No. of eyes } \\
\text { with chronic } \\
\text { type of } \\
\text { endo- } \\
\text { phthalmitis: } \\
>6 \text { weeks }\end{array}$ & $\begin{array}{c}\text { Total } \\
\text { no. }(\%) \\
\end{array}$ & $\begin{array}{l}\text { No. of } \\
\text { eyes with } \\
\text { chronic } \\
\text { type of } \\
\text { endo- } \\
\text { phthalmitis: } \\
>6 \text { weeks }\end{array}$ \\
\hline $\begin{array}{l}\text { 1. Vitreous humour } \\
\text { alone collected }\end{array}$ & 40 & 19 & 0 & 6 & 13 & 21 & 0 & 7 & 14 & NA & NA & NA & NA & NA & NA \\
\hline $\begin{array}{l}\text { 2. Anterior and } \\
\text { vitreous humour } \\
\text { were collected }\end{array}$ & 326 & 206 & 28 & 115 & 63 & 120 & 23 & 67 & 30 & NA & NA & NA & NA & NA & NA \\
\hline $\begin{array}{l}\text { 3. Anterior and } \\
\text { vitreous humour, } \\
\text { and corneal scrapes }\end{array}$ & 31 & NA & NA & NA & NA & NA & NA & NA & NA & 31 & 31 & NA & NA & NA & NA \\
\hline $\begin{array}{l}\text { 4. Both vitreous } \\
\text { humour and } \\
\text { corneal scrapes }\end{array}$ & 12 & NA & NA & NA & NA & NA & NA & NA & NA & 12 & 12 & NA & NA & NA & NA \\
\hline $\begin{array}{l}\text { 5. Both vitreous } \\
\text { humour and } \\
\text { scleral scrapes }\end{array}$ & 4 & NA & NA & NA & NA & NA & NA & NA & NA & NA & NA & 4 & 4 & NA & NA \\
\hline $\begin{array}{l}\text { were collected } \\
6 . \text { Anterior and } \\
\text { vitreous humour, } \\
\text { and blood } \\
\text { specimens were } \\
\text { collected }\end{array}$ & 3 & NA & NA & NA & NA & NA & NA & NA & NA & NA & NA & NA & NA & 3 & 3 \\
\hline \multirow{2}{*}{$\begin{array}{l}\text { 7. Both vitreous } \\
\text { humour and blood } \\
\text { specimens were } \\
\text { collected }\end{array}$} & 8 & NA & NA & NA & NA & NA & NA & NA & NA & NA & NA & NA & NA & 8 & 8 \\
\hline & 424 & $225(53.1)$ & 28/225 (12.4) & $121 / 225$ (53.8) & $76 / 225$ (33.8) & 141 (33.3) & $23 / 141$ (16.3) & 74/141 (52.5) & $44 / 141$ & $43(10.1)$ & $43 / 43(100)$ & $4(0.94)$ & $4 / 4(100)$ & $11(2.6)$ & $11 / 11(100)$ \\
\hline
\end{tabular}

NA: not applicable. 
Table 3 Microbial pathogens recovered from intraocular aspirates, corneal scrapes, scleral scrapes, and blood specimens collected from patients with infectious endophthalmitis presenting at a tertiary eye care referral centre in South India

\begin{tabular}{|c|c|c|c|c|c|c|c|c|c|c|c|c|c|c|c|c|}
\hline \multirow[t]{3}{*}{$\begin{array}{l}\text { Sl. } \\
\text { no. }\end{array}$} & \multirow[t]{3}{*}{$\begin{array}{l}\text { Microbial isolates } \\
\text { recovered from eyes } \\
\text { with infectious } \\
\text { endophthalmitis }\end{array}$} & \multirow[t]{3}{*}{$\begin{array}{l}\text { Total } \\
\text { no. of } \\
\text { isolates } \\
(\%)\end{array}$} & \multicolumn{12}{|c|}{ Microorganisms recovered from eyes with exogenous endophthalmitis } & \multicolumn{2}{|c|}{$\begin{array}{l}\text { Microorganisms } \\
\text { recovered from } \\
\text { eyes with } \\
\text { endogenous } \\
\text { enophthalmitis }\end{array}$} \\
\hline & & & \multicolumn{4}{|c|}{$\begin{array}{l}\text { Eyes with endophthalmitis after } \\
\text { intraocular surgeries }\end{array}$} & \multicolumn{4}{|c|}{$\begin{array}{c}\text { Eyes with endophthalmitis after } \\
\text { penetrating ocular injuries }\end{array}$} & \multicolumn{2}{|c|}{$\begin{array}{l}\text { Endophthalmitis } \\
\text { associated with } \\
\text { microbial keratitis }\end{array}$} & \multicolumn{2}{|c|}{$\begin{array}{l}\text { Eyes with } \\
\text { endophthalmitis } \\
\text { associated with } \\
\text { scleral abscess }\end{array}$} & \multirow[t]{2}{*}{$\begin{array}{l}\text { Total } \\
\text { no. } \\
(\%)\end{array}$} & \multirow{2}{*}{$\begin{array}{c}\text { Eyes with } \\
\text { chronic } \\
\text { type of } \\
\text { endo- } \\
\text { phthalmitis } \\
>6 \text { weeks }\end{array}$} \\
\hline & & & $\begin{array}{l}\text { Total } \\
\text { no. } \\
(\%)\end{array}$ & $\begin{array}{l}\text { Eyes with } \\
\text { fulminant } \\
\text { type of } \\
\text { endo- } \\
\text { phthalmitis: } \\
<4 \text { days }\end{array}$ & $\begin{array}{l}\text { Eyes with } \\
\text { acute } \\
\text { type of } \\
\text { endo- } \\
\text { phthalmitis: } \\
4 \text { days-6 } \\
\text { weeks }\end{array}$ & $\begin{array}{l}\text { Eyes with } \\
\text { chronic } \\
\text { type of } \\
\text { endo- } \\
\text { phthalmitis: } \\
>6 \text { weeks }\end{array}$ & $\begin{array}{l}\text { Total } \\
\text { no. } \\
(\%)\end{array}$ & $\begin{array}{l}\text { Eyes with } \\
\text { fulminant } \\
\text { type of } \\
\text { endo- } \\
\text { phthalmitis: } \\
<4 \text { days }\end{array}$ & $\begin{array}{l}\text { Eyes with } \\
\text { acute type of } \\
\text { endo- } \\
\text { phthalmitis: } \\
4 \text { days-6 } \\
\text { weeks }\end{array}$ & $\begin{array}{l}\text { Eyes with } \\
\text { chronic } \\
\text { type of } \\
\text { endo- } \\
\text { phthalmitis: } \\
>6 \text { weeks }\end{array}$ & $\begin{array}{l}\text { Total } \\
\text { no. } \\
(\%)\end{array}$ & $\begin{array}{c}\text { Eyes with } \\
\text { chronic } \\
\text { type of } \\
\text { endo- } \\
\text { ph thalmitis: } \\
>6 \text { weeks }\end{array}$ & $\begin{array}{l}\text { Total } \\
\text { no. } \\
(\%)\end{array}$ & $\begin{array}{l}\text { Eyes with } \\
\text { chronic } \\
\text { type of } \\
\text { endo- } \\
\text { phthalmitis: } \\
>6 \text { weeks }\end{array}$ & & \\
\hline \multirow[t]{18}{*}{1} & Total no. of bacterial isolates & $364(85.8)$ & $213(94.7)$ & 28 & 118 & 67 & $109(77.8)$ & 23 & 65 & 21 & $27(62.8)$ & 27 & $4(100)$ & 4 & $11(100)$ & 7 \\
\hline & (i). No. of Gram-positive cocci & $233(55)$ & $162(72)$ & 7 & 97 & 58 & $55(39)$ & 5 & 35 & 15 & $7(16.3)$ & 7 & $2(50)$ & 2 & $7(63.6)$ & 7 \\
\hline & Coagulase-positive staphylococci & 111 & 83 & 6 & 76 & 1 & 27 & 1 & 13 & 13 & & & & & 1 & 1 \\
\hline & Staphylococcus aureus & 14 & 7 & & 7 & & 3 & & 3 & & 1 & 1 & 1 & 1 & 2 & 2 \\
\hline & Streptococcus pneumoniae & 81 & 62 & 1 & 13 & 48 & 9 & 2 & 7 & & 6 & 6 & 1 & 1 & 3 & 3 \\
\hline & Streptococcus viridans & 27 & 10 & & 1 & 9 & 16 & 2 & 12 & 2 & & & & & 1 & 1 \\
\hline & (ii). No. of Gram-positive bacilli & $30(7.1)$ & $6(2.7)$ & 0 & 3 & 3 & $23(16.3)$ & 2 & 21 & 0 & $1(2.3)$ & 1 & 0 & 0 & 0 & 0 \\
\hline & Corynebacterium spp. & 15 & 6 & & 3 & 3 & 9 & 1 & 8 & & & & & & & \\
\hline & Bacillus spp. & 15 & 0 & & & & 14 & 1 & 13 & & 1 & 1 & & & & \\
\hline & (iii). No. of actinomycetes & $24(5.7)$ & $10(4.4)$ & 0 & 4 & 6 & $10(7)$ & 1 & 3 & 6 & $3(7)$ & 3 & $1(25)$ & 1 & 0 & 0 \\
\hline & Nocardia spp. & 24 & 10 & & 4 & 6 & 10 & 1 & 3 & 6 & 3 & 3 & 1 & 1 & & \\
\hline & (iv). No. of Gram-negative bacilli & 77 (18.2) & $35(15.6)$ & 21 & 14 & 0 & $21(14.9)$ & 15 & 6 & 0 & $16(37.3)$ & 16 & $1(25)$ & 1 & $4(36.4)$ & 4 \\
\hline & Pseudomonas aeruginosa & 42 & 20 & 12 & 8 & & 8 & 6 & 2 & & 11 & 11 & 1 & 1 & 2 & 2 \\
\hline & E. coli & 12 & 6 & 4 & 2 & & 3 & 2 & 1 & & 2 & 2 & & & 1 & 1 \\
\hline & Klebsiella spp. & 9 & 2 & 2 & & & 4 & 2 & 2 & & 2 & 2 & & & 1 & 1 \\
\hline & Proteus mirabilis & 3 & 1 & 1 & & & 1 & 1 & & & 1 & 1 & & & & \\
\hline & Enterobacter spp. & 8 & 5 & 2 & 3 & & 3 & 2 & 1 & & & & & & & \\
\hline & Acinetobacter spp. & 3 & 1 & & 1 & & 2 & 2 & & & & & & & & \\
\hline \multirow[t]{9}{*}{2} & Total no. of fungal isolates & $60(14.2)$ & $12(5.3)$ & 0 & 3 & 9 & $32(22.7)$ & 0 & 9 & 23 & $16(37.2)$ & 16 & 0 & 0 & 0 & 0 \\
\hline & (i). Yeast-like organisms & $2(0.5)$ & $1(0.4)$ & 0 & 0 & 1 & $1(0.7)$ & 0 & 0 & 1 & $0(0)$ & 0 & 0 & 0 & 0 & 0 \\
\hline & Candida albicans & 2 & 1 & & & 1 & 1 & & & 1 & & & & & & \\
\hline & (ii). Filamentous fungus & $58(13.7)$ & $11(4.9)$ & & 3 & 8 & $31(22)$ & & 9 & 22 & $16(37.2)$ & 16 & 0 & 0 & 0 & 0 \\
\hline & Aspergillus spp. & 36 & 8 & & 2 & 6 & 18 & & 5 & 13 & 10 & 10 & & & & \\
\hline & Fusarium spp. & 20 & 3 & & 1 & 2 & 13 & & 4 & 9 & 4 & 4 & & & & \\
\hline & Bipolaris sp. & 1 & 0 & & & & & & & & 1 & 1 & & & & \\
\hline & Curvularia sp. & 1 & 0 & & & & & & & & 1 & 1 & & & & \\
\hline & Total no. of isolates (\%) & $424(100)$ & $225(100)$ & 28 & 121 & 76 & $141(100)$ & 23 & 74 & 44 & $43(100)$ & 43 & $4(100)$ & 4 & $11(100)$ & 11 \\
\hline
\end{tabular}


post-surgical endophthalmitis, Gram-negative bacilli (75\%; 21 of 28) were the predominant cause for developing fulminant infection, Staphylococcus spp. (68.6\%; 83 of 121) for acute infection, and Streptococcus spp. (75\%; 57 of 76) for chronic infection, whereas among cases of post-traumatic endophthalmitis, Gram-negative bacilli (65.2\%; 15 of 23) were the most common cause for fulminant infection, Gram-positive bacilli (28.4\%; 21 of 74), Streptococcus spp. (25.7\%; 19 of 74), and Staphylococcus spp. $(21.6 \% ; 16$ of 74$)$ acute infection and fungi $(52.3 \% ; 23$ of 44$)$ chronic infection. The predominant microbial pathogen causing endophthalmitis associated with microbial keratitis was filamentous fungi $(37.2 \%$; 16 of 43$)$ and Gram-negative bacilli $(37.2 \% ; 16$ of 43$)$, followed by $S$. pneumoniae (14\%; 6 of 43). Gram-negative bacilli (36.4\%; 4 of 11) and Streptococcus spp. (36.4\%; 3 of 11) were predominant isolates from patients with $\mathrm{EE}$.

A total of $111 \mathrm{CoNS}$ were isolated; their prevalence was significantly higher in acute onset post-surgical endophthalmitis (73.9\%; 82 of 111 total CoNS isolates) than the prevalence of CoNS in other forms of endophthalmitis $(26.1 \%$; 29 of 111$)(P<0.0001)$, whereas S. pneumoniae was more prevalent in chronic onset postsurgical endophthalmitis $(59.3 \%$; 48 of 81 total isolates) than in other forms of endophthalmitis (40.7\%; 33 of 81) $(P<0.0001)$. Gram-positive bacilli produced significantly higher numbers of acute onset post-traumatic endophthalmitis $(70 \% ; 21$ of 30 total isolates) than other forms of endophthalmitis $(30 \% ; 9$ of 30$)(P<0.0001)$. Nocardia spp. were more frequently found in chronic onset post-surgical $(25 \%, 6$ of 24 total isolates, $P=0.073)$, post-traumatic $(25 \%, 6$ of $24, P=0.041)$, and endophthalmitis associated with microbial keratitis $(100 \% ; 3$ of 3). Gram-negative bacilli were frequently associated with fulminant onset than acute or chronic onset in both post-surgical (27.3\%, 21 of 77 total Gramnegative bacilli, $P<0.001)$ and post-traumatic endophthalmitis $(19.5 \%, 15$ of $77, P<0.001)$. Filamentous fungi were found predominantly among cases with posttraumatic endophthalmitis $(53.5 \%$; 31 of 58 total fungal isolates) compared to endophthalmitis associated with microbial keratitis $(27.6 \%, 16$ of $58, P=0.058)$ and postsurgical endophthalmitis $(19 \%, 11$ of $58, P<0.001)$. The prevalence of Gram-positive bacilli was found to be higher in causing post-traumatic endophthalmitis $(76.7 \%$; 23 of 30 total isolates) rather than other forms of endophthalmitis $(23.3 \%$; 7 of 30$)(P<0.001)$.

The antibacterial susceptibilities of bacterial isolates recovered from eyes with endophthalmitis are presented in Table 4. The highest percentage of Gram-positive cocci were susceptible to both cefazolin $(100 \%)$ and moxifloxacin (100\%) followed by chloramphenicol (98.3\%), vancomycin (96.6\%), and gatifloxacin $(95.3 \%)$. The Gram-positive bacilli were susceptible in highest percentage to amikacin (100\%) and all four tested fluoroquinolones, ciprofloxacin (100\%), ofloxacin (100\%), gatifloxacin (100\%), and moxifloxacin (100\%). Amikacin $(100 \%)$, gatifloxacin $(100 \%)$, and moxifloxacin $(100 \%)$ showed highest efficacy against Nocardia spp. of endophthalmitis isolates. The highest percentage of Gram-negative bacilli were susceptible to gatifloxacin $(100 \%)$, amikacin $(100 \%)$, ciprofloxacin $(97.4 \%)$, and ofloxacin (97.4\%). Overall, gatifloxacin (97.7\%) showed the highest activity against bacterial endophthalmitis isolates followed by ciprofloxacin (95.9\%) and ofloxacin (95.1\%). A comparative analysis of the antibacterial susceptibilities of bacterial isolates, according to the clinical settings, is presented in Table 5 .

\section{Discussion}

A wide range of microorganisms that enter the eye from the external environment or by haematogenous spread cause endophthalmitis. Recovery of these causative organisms is an important step in the management of infective endophthalmitis. The rate of recovery depends on the clinical settings, method of specimen collection and inoculation, load of viable microbes in the inoculum, previous medical therapy, and the environment in which the inoculated plates are incubated. ${ }^{17-19}$ In this study, $100 \%$ recovery rate achieved in endophthalmitis following corneal and scleral infections, whereas it accounted for $65 \%$ in post-traumatic (141 of 217), 36\% in post-surgical (225 of 625), and $15.5 \%$ in EE (11 of 71). In comparison, higher recovery rates are documented in many studies from postoperative endophthalmitis $(67 \%$ in EVS,,${ }^{9,16} 53 \%$ in South India, ${ }^{20} 60 \%$ in Canada ${ }^{21}{ }^{21} 67 \%$ in Australia, ${ }^{22}$ and $75 \%$ in Sweden ${ }^{23}$ ). Many factors may have contributed to this, the most likely factor being that the patients were treated for infections before they were referred to tertiary care. On the other hand, the high rates in corneal and scleral infections could have been due to a large load of virulent organisms.

We found that bacteria $(85.8 \% ; 364$ of 424$)$ were followed by fungi $(14.2 \%$; 60 of 424$)$ as the most common causative organisms, supported by Puliafito $e t a l^{8}$ study. The most frequently isolated bacterial species were CoNS (26.2\%; 111 of 424) followed by S. pneumoniae $(19.1 \% ; 81$ of 424), similar to the findings in various other studies. ${ }^{2,8}$ We found that CoNS $(62.8 \% ; 76$ of 121) were the principal cause for acute post-surgical endophthalmitis along with S. pneumoniae (10.7\%; 13 of 121), compared to the Gramnegative bacilli (75\%; 21 of 28), especially $P$. aeruginosa (43\%; 12 of 28), for fulminant onset. These findings are similar to those in various studies. ${ }^{6,24,25}$ In comparison, the predominant cause for chronic post-surgical endophthalmitis was Streptococcus species (75\%; 57 of 76) followed by fungi $(11.8 \%$; 9 of 76$)$. This, however, is in 
Table 4 In vitro antibacterial susceptibilities of bacterial isolates recovered from intraocular aspirates, corneal scrapes, scleral scrapes, and blood specimens collected from patients with infectious endophthalmitis presenting at a tertiary eye care referral centre in South India between January 1997 and December 2006

\begin{tabular}{|c|c|c|c|c|c|c|c|c|c|c|c|c|c|}
\hline \multirow{2}{*}{$\begin{array}{l}\text { Microbial isolates } \\
\text { recovered from eyes } \\
\text { with infectious } \\
\text { endophthalmitis }\end{array}$} & \multicolumn{13}{|c|}{$\begin{array}{l}\text { No. of the susceptible bacterial isolates/no. of the tested isolates (\% of the susceptible isolates) } \\
\text { against common antibacterial agents by Kirby-Bauer disc diffusion methods }\end{array}$} \\
\hline & $C z$ & $\mathrm{Ce}$ & $\mathrm{Ca}$ & $A k$ & $T b$ & $G$ & $N x$ & $C f$ & Of & $G f$ & Mo & $\mathrm{Ch}$ & $V a$ \\
\hline
\end{tabular}

(i). Total no. $\quad 233 / 233$ (100) 208/233 (89.3) 216/233 (92.7) 134/233 (57.5) 128/233 (54.9) 128/233 (54.9) 214/233 (91.9) 222/233 (95.3) 219/233 (94) $55 / 57$ (96.5) $57 / 57$ (100) 229/233 (98.3) 225/233 (96.6)
of Gram-positive

cocci

cocci

Coagulasepositive $111 / 111$ (100)
staphylococci staphylococci

Staphylococcus

aureus

Streptococcus

pneumoniae

$14 / 14(100)$

87

14 (85.7)

$2 / 14(85.7)$

$12 / 14(85.7)$

$12 / 14(85.7) \quad 5 / 5(100) \quad 4 / 4(100)$

14/14 (100) 14/14 (100)

viridans

Gram-positive

bacilli

Corynebacterium

spp.

Bacillus spp.

$5 / 81(6.2) \quad 16 / 8$

/81 (19.8) $16 / 81$

78.8) $78 / 81(96.3) \quad 81 / 81(100) \quad 81 / 8$

/81 (100) 18/18 (100) 18/18 (100) $\quad 81 / 81$ (100) $\quad 76 / 81$ (93.8)

(iii). Total no.

of aerobic

actinomycetes

Nocardia spp.

(iv). Total no. of

Gram-negative

bacilli

Pseudomonas

aeruginosa

E. coli

Klebsiella spp.

Proteus mirabilis

Enterobacter spp.

susceptible

isolates/no. of

tested isolates

(\% of the

susceptible

isolates)

Cz: cefazolin; Ce: cephotaxime; Ca: Ceftazidime; Ak: amikacin; Tb: tobramycin; G: gentamicin; Nx: norfloxacin; Cf: ciprofloxacin; Of: ofloxacin; Gf: gatifloxacin; Mo: moxifloxacin; Ch: chloraphenicol; Va: vancomycin. 
Table 5 Comparative in vitro antibacterial susceptibilities of bacterial isolates recovered from eyes with endophthalmitis according to the clinical settings

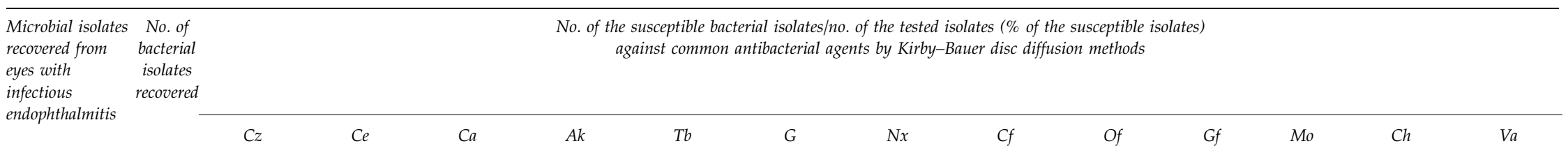

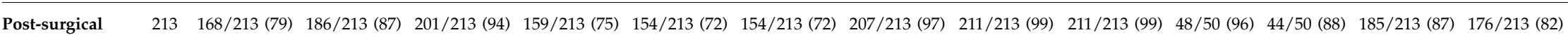
endophthalmitis

Gram-positive 162 162/162 (100) 154/162 (95.1)159/162 (98.2)108/162 (66.7)107/162 (66.1)107/162 (66.1)160/162 (98.8)160/162 (98.8)160/162 (98.8)34/36 (94.4)36/36 (100) 161/162 (99.4)162/162 (100) cocci

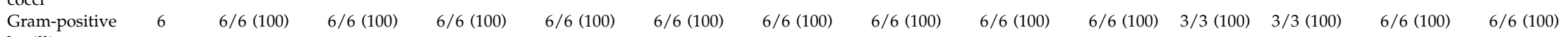

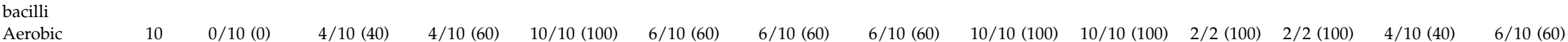

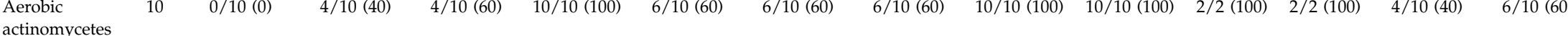

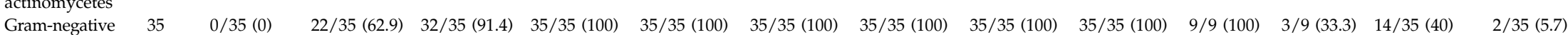
bacilli

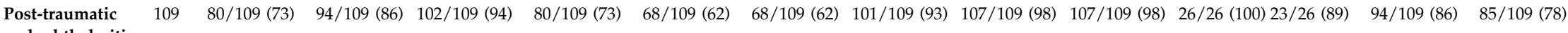

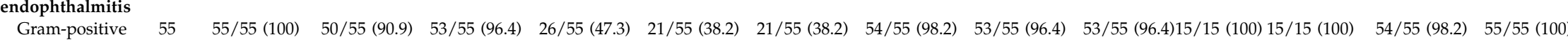
coccis $\begin{array}{lllllllllllllllll}\text { Gram-positive } & 23 & 23 / 23(100) & 19 / 23(82.6) & 21 / 23(91.3) & 23 / 23(100) & 21 / 23(91.3) & 21 / 23(91.3) & 21 / 23(91.3) & 23 / 23(100) & 23 / 23(100) & 5 / 5(100) & 5 / 5(100) & 20 / 23(87) & 20 / 23(87)\end{array}$

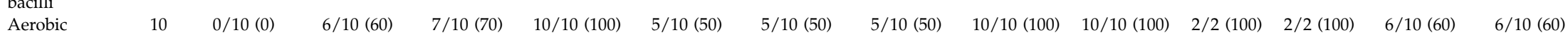
$\begin{array}{lllllllllllllll}\text { Aerobic } & 10 & 0 / 10(0) & 6 / 10(60) & 7 / 10(70) & 10 / 10(100) & 5 / 10(50) & 5 / 10(50) & 5 / 10(50) & 10 / 10(100) & 10 / 10(100) & 2 / 2(100) & 2 / 2(100) & 6 / 10(60) & 6 / 10(60) \\ \text { Gram-negative } & 21 & 2 / 21(9.5) & 19 / 21(90.5) & 21 / 21(100) & 21 / 21(100) & 21 / 21(100) & 21 / 21(100) & 21 / 21(100) & 21 / 21(100) & 21 / 21(100) & 4 / 4(100) & 1 / 4(25) & 14 / 21(66.7) & 4 / 21(19)\end{array}$ bacilli

\begin{tabular}{|c|c|c|c|c|c|c|c|c|c|c|c|c|c|c|}
\hline $\begin{array}{l}\text { Associated } \\
\text { with microbial } \\
\text { keratitis }\end{array}$ & 27 & $7 / 27$ (26) & 4/27 (15) & $6 / 27(22)$ & $17 / 27(63)$ & $9 / 27$ (33) & $9 / 27$ (33) & $12 / 27(44)$ & $22 / 27(82)$ & $19 / 27(70)$ & $5 / 27$ (19) & $3 / 27$ (11) & $10 / 27(37)$ & 4/27 (15) \\
\hline $\begin{array}{l}\text { Gram-positive } \\
\text { cocci }\end{array}$ & 7 & $7 / 7$ (100) & $2 / 7(28.6)$ & 2/7 (28.6) & $0 / 7(0)$ & $0 / 7(0)$ & 0/7 (0) & $0 / 7(0)$ & 6/7 (85.7) & $3 / 7(42.9)$ & $2 / 3(66.7)$ & $2 / 3(66.7)$ & 6/7 (85.7) & $4 / 7(57.1)$ \\
\hline $\begin{array}{l}\text { Gram-positive } \\
\text { bacilli }\end{array}$ & 1 & $0 / 1(0)$ & $0 / 1(0)$ & $0 / 1(0)$ & 1/1 (100) & $0 / 1(0)$ & $0 / 1(0)$ & $0 / 1(0)$ & 1/1 (100) & 1/1 (100) & NA & NA & $01 /(0)$ & $0 / 1(0)$ \\
\hline $\begin{array}{l}\text { Aerobic } \\
\text { actinomycetes }\end{array}$ & 3 & $0 / 3(0)$ & 0/3 (0) & $0 / 3(0)$ & $3 / 3(100)$ & $1 / 3(33.3)$ & $1 / 3(33.3)$ & $1 / 3(33.3)$ & $1 / 3(33.3)$ & $1 / 3(33.3)$ & 1/1 (100) & 1/1 (100) & $0 / 3(0)$ & $0 / 3(0)$ \\
\hline $\begin{array}{l}\text { Gram-negative } \\
\text { bacilli }\end{array}$ & 16 & $0 / 16(0)$ & 2/16 (12.5) & 4/16 (25) & $13 / 16(81.2)$ & $8 / 16(50)$ & 8/16 (100) & 11/16 (68.8) & 14/16 (87.5) & $14 / 16(87.5)$ & 2/2 (100) & $0 / 2(0)$ & $4 / 16$ & 0/16 (0) \\
\hline $\begin{array}{l}\text { Associated } \\
\text { with scleral } \\
\text { abscess }\end{array}$ & 4 & $2 / 4(50)$ & 0/4 (0) & $0 / 4(0)$ & $2 / 4(50)$ & $1 / 4(25)$ & $1 / 4(25)$ & $1 / 4(25)$ & 3/4 (75) & $3 / 4(75)$ & $3 / 4(75)$ & $3 / 4$ (75) & 2/4 (50) & $0 / 4(0)$ \\
\hline $\begin{array}{l}\text { Gram-postive } \\
\text { cocci }\end{array}$ & 2 & 2/2 (100) & 0/2(0) & $02 /(0)$ & $0 / 2(0)$ & $0 / 2(0)$ & $0 / 2(0)$ & $0 / 2(0)$ & $1 / 2(50)$ & $1 / 2(50)$ & 2/2 (100) & 2/2 (100) & $1 / 2(50)$ & $0 / 2(0)$ \\
\hline $\begin{array}{l}\text { Gram-positive } \\
\text { bacilli }\end{array}$ & 0 & NA & NA & NA & NA & NA & NA & NA & NA & NA & NA & NA & NA & NA \\
\hline $\begin{array}{l}\text { Aerobic } \\
\text { actinomycetes }\end{array}$ & 1 & 0/1 (0) & 0/1 (0) & $0 / 1(0)$ & $1 / 1(100)$ & $0 / 1(0)$ & 0/1 (0) & $0 / 1(0)$ & $1 / 1(100)$ & 1/1 (100) & $1 / 1(100)$ & 1/1 (100) & 0/1 (0) & $0 / 1(0)$ \\
\hline $\begin{array}{l}\text { Gram-negative } \\
\text { bacilli }\end{array}$ & 1 & $0 / 1(0)$ & 0/1 (0) & 0/1 (0) & 1/1 (100) & 1/1 (100) & 1/1 (100) & 1/1 (100) & 1/1 (100) & 1/1 (100) & NA & NA & 1/1 (100) & $0 / 1(0)$ \\
\hline
\end{tabular}


Table 5 (Continued)

\begin{tabular}{|c|c|c|c|c|c|c|c|c|c|c|c|c|c|c|}
\hline \multirow{2}{*}{$\begin{array}{l}\text { Microbial isolates } \\
\text { recovered from } \\
\text { eyes with } \\
\text { infectious } \\
\text { endophthalmitis }\end{array}$} & \multirow{2}{*}{$\begin{array}{c}\text { No. of } \\
\text { bacterial } \\
\text { isolates } \\
\text { recovered }\end{array}$} & \multicolumn{13}{|c|}{$\begin{array}{c}\text { No. of the susceptible bacterial isolates/no. of the tested isolates (\% of the susceptible isolates) } \\
\text { against common antibacterial agents by Kirby-Bauer disc diffusion methods }\end{array}$} \\
\hline & & $C z$ & $\mathrm{Ce}$ & $\mathrm{Ca}$ & $A k$ & $T b$ & G & $N x$ & $C f$ & Of & Gf & Mo & $C h$ & $V a$ \\
\hline $\begin{array}{l}\text { Endogenous } \\
\text { endophthalmitis }\end{array}$ & 11 & $7 / 11(64)$ & 2/11 (18) & 4/11 (36) & $4 / 11(36)$ & $4 / 11(36)$ & $4 / 11(36)$ & $4 / 11(36)$ & 6/11 (55) & 6/11 (55) & $3 / 3(100)$ & $2 / 3(67)$ & 9/11 (82) & $4 / 11(36)$ \\
\hline $\begin{array}{l}\text { Gram-positive } \\
\text { cocci }\end{array}$ & 7 & $7 / 7$ (100) & 2/7 (28.6) & 2/7 (28.6) & $0 / 7(0)$ & 0/7 (0) & 0/7 (0) & 0/7 (0) & $0 / 7(0)$ & 2/7 (28.6) & $2 / 2(100)$ & $2 / 2(100)$ & $7 / 7$ (100) & $4 / 7$ (57.1) \\
\hline $\begin{array}{l}\text { Gram-positive } \\
\text { bacilli }\end{array}$ & 0 & NA & NA & NA & NA & NA & NA & NA & NA & NA & NA & NA & NA & NA \\
\hline $\begin{array}{l}\text { Aerobic } \\
\text { actinomycetes }\end{array}$ & 0 & NA & NA & NA & NA & NA & NA & NA & NA & NA & NA & NA & NA & NA \\
\hline $\begin{array}{l}\text { Gram-negative } \\
\text { bacilli }\end{array}$ & 4 & 0/4 (0) & 0/4 (0) & $2 / 4(50)$ & 4/4 (100) & 4/4 (100) & 4/4 (100) & 4/4 (100) & 4/4 (100) & 4/4 (100) & $1 / 1(100)$ & 0/1 (0) & $2 / 4(50)$ & $0 / 4(0)$ \\
\hline
\end{tabular}

Total no.

364 264/364 (72.5)286/364 (78.6)313/364 (86.0)262/364 (72.0)236/364 (64.8)236/364 (64.8)325/364 (89.3)349/364 (95.9)346/364 (95.1)85/87 (97.7)75/87 (86.2)300/364 (82.4)269/364 (73.9)

of susceptible

isolates/no. of

tested isolates

(\% of

susceptible

isolates)

Cz: cefazolin; Ce: cephotaxime; Ca: Ceftazidime; Ak: amikacin; Tb: tobramycin; G: gentamicin; Nx: norfloxacin; Cf: ciprofloxacin; Of: ofloxacin; Gf: gatifloxacin; Mo: moxifloxacin; Ch: chloraphenicol; Va: vancomycin; NA: not applicable. 
contrast with the findings by Anand et al (4.8\% of Streptococcus spp.) who showed a higher rate of fungal infection $(35.7 \%) .{ }^{24}$ In our study, the most common fungal isolates were Aspergillus spp. (7.9\%; 6 of 76), in contrast with studies from the Western countries. ${ }^{26-28}$

In post-traumatic endophthalmitis, the predominant organisms identified were filamentous fungi $(22 \% ; 31$ of 141), followed by CoNS (19\%; 27 of 141), and Grampositive bacilli $(16.3 \%$; 23 of 141). In fulminant cases, Gram-negative bacilli were predominant $(65.2 \%$; 15 of 23), whereas in acute onset, Bacillus sp. (17.6\%; 13 of 74) and CoNS $(17.6 \% ; 13$ of 74$)$ followed by Streptococcus viridans $(16.2 \% ; 12$ of 74$)$ were frequently isolated. Filamentous fungi $(50 \% ; 22$ of 44$)$ were the major cause of chronic onset post-traumatic endophthalmitis in our study. A study review of the literature shows that posttraumatic endophthalmitis is associated with a wide variety of micro-organisms derived from the environment, ${ }^{2-4}$ and Bacillus spp. and fungi, respectively, have been reported as the second and third most common organisms after staphylococci. ${ }^{2,4,6}$ Bacillus endophthalmitis develops particularly in the setting of retained intraocular foreign bodies, ${ }^{29}$ whereas fungal endophthalmitis is mainly associated with intraocular injuries with vegetable matter or soil contamination. ${ }^{2,30}$

In cases of endophthalmitis associated with microbial keratitis, the most common isolates were Gram-negative bacteria (37.2\%; 16 of 43 ) and fungi $(37.2 \% ; 16$ of 43$)$, comparable to the findings of Scott et al. ${ }^{7}$ Patients with microbial keratitis caused by unusually virulent organisms or the ones not responding to medical therapy are more likely to develop endophthalmitis. In vitro susceptibility testing of the organism recovered from cases with microbial keratitis showed high virulent and multi-drug resistance due to topical antimicrobial therapy. Scleral abscess was caused by Pseudomonas aeruginosa, S. pneumoniae, S. aureus, Proteus, and Nocardia spp. as well as atypical mycobacteria infection. ${ }^{31}$ Such virulent organisms causing diffuse scleral infection may spread to infect intraocular tissue leading to endophthalmitis. In the current series, endophthalmitis associated with scleral abscess is encountered in a few cases owing to Nocardia sp., Pseudomonas aeruginosa, S. aureus, and S. pneumoniae, and these isolates are resistant to most of the commonly used antibacterials.

Endogenous endophthalmitis occurs when organisms reach the eye through the bloodstream. A review of the literature shows that EE comprises $2-17 \%$ of the cases of infectious endophthalmitis. ${ }^{5}$ In the current series, it is estimated at $2.6 \%$ (11 of 424 ) of all culture-proven endophthalmitis. The most common cause for EE identified in this study is Gram-positive cocci $(63.6 \% ; 7$ of $11)$, of which S. pneumoniae $(27.3 \% ; 3$ of 11$)$ and S. aureus $(18.2 \% ; 2$ of 11$)$ are predominantly isolated.
Gram-negative bacilli are responsible for 36.4\% (4 of 11) of the EE; including, Pseudomonas aeruginosa $(18.2 \% ; 2$ of 11), E. coli $(9 \% ; 1$ of 11$)$ and Klebsiella pneumoniae $(9 \% ; 1$ of 11). Unlike postoperative endophthalmitis, EE is rarely caused by CoNS. Similarly, Streptococcus species and $S$. aureus have been reported to be the predominant bacterial pathogens causing EE. ${ }^{9,10}$ Conversely, a higher incidence of enteric Gram-negative microorganisms causing EE has been reported in many series with predominance of Klebsiella spp. and E. coli. ${ }^{2}$ Wong et al reported the increased incidence of Klebsiella spp. EE in the East Asian region. ${ }^{32}$ Another trend is the increasing incidence of Pseudomonas EE among patients with cystic fibrosis, immunosuppression, and endocarditis. ${ }^{33}$

In this study, the fourth-generation fluoroquinolone, gatifloxacin $(97.7 \%$; 85 of 87$)$ demonstrated greatest activities against endophthalmitis bacterial isolates followed by second-generation fluoroquinolones, ciprofloxacin $(95.9 \% ; 349 / 364)$, and ofloxacin $(95.1 \% ; 346$ of 364). The other fourth-generation fluoroquinolone, moxifloxacin revealed a higher rate of efficacy against Gram-positive cocci (100\%; 57/57), Gram-positive bacilli $(100 \% ; 8$ of 8$)$, and Nocardia spp. $(100 \% ; 6 / 6)$. The firstgeneration cephalosporin, cefazolin, shows higher effectiveness against Gram-positive cocci $(100 \%$; 233 of 233 ), compared to third-generation drugs (cefotaxime $(89 \% ; 208$ of 233$)$ and ceftazidime $(92.7 \% ; 216$ of 233)). Among aminoglycosides, amikacin revealed higher efficacy against gram-positive bacilli (100\%; 30 of 30), Nocardia spp. (100\%; 24 of 24), and Gram-negative bacilli (96\%; 74 of 77). Similarly, Anand et al ${ }^{24}$ reported a higher activity of cefazolin $(92.6 \%)$ against Gram-positive isolates and ciprofloxacin (73.2\%) against Gram-negative isolates. Chloramphenicol, a broad-spectrum antibiotic, showed a higher rate of efficacy against Gram-positive cocci $(98.3 \%$; 229 of 233); however, chloramphenicol is not routinely used because of its toxicity.

The analysis on the in vitro susceptibility pattern shows variation among the susceptibility of isolates from different clinical settings. It is thought that with frequent and persistent long-term use of a given antibiotic, there is a greater chance of bacterial strains developing resistance to that drug. ${ }^{34,35}$ High antibiotic resistance strains of bacteria recovered from endophthalmitis associated with scleral abscess, with microbial keratitis, and with EE suggest the same. The percentage of susceptibility was less in these cases compared to post-surgical and posttraumatic endophthalmitis (Table 5 and Figure 1). The indiscriminate use or misuse and prolonged antibiotic use appear to be a major factor in the development of drug resistance, as also the transformation of drugresistant plasmid or DNA molecule among normal flora of extra-ocular surface. ${ }^{35}$ It must be noted that the conventional Kirby-Bauer disc diffusion method of 


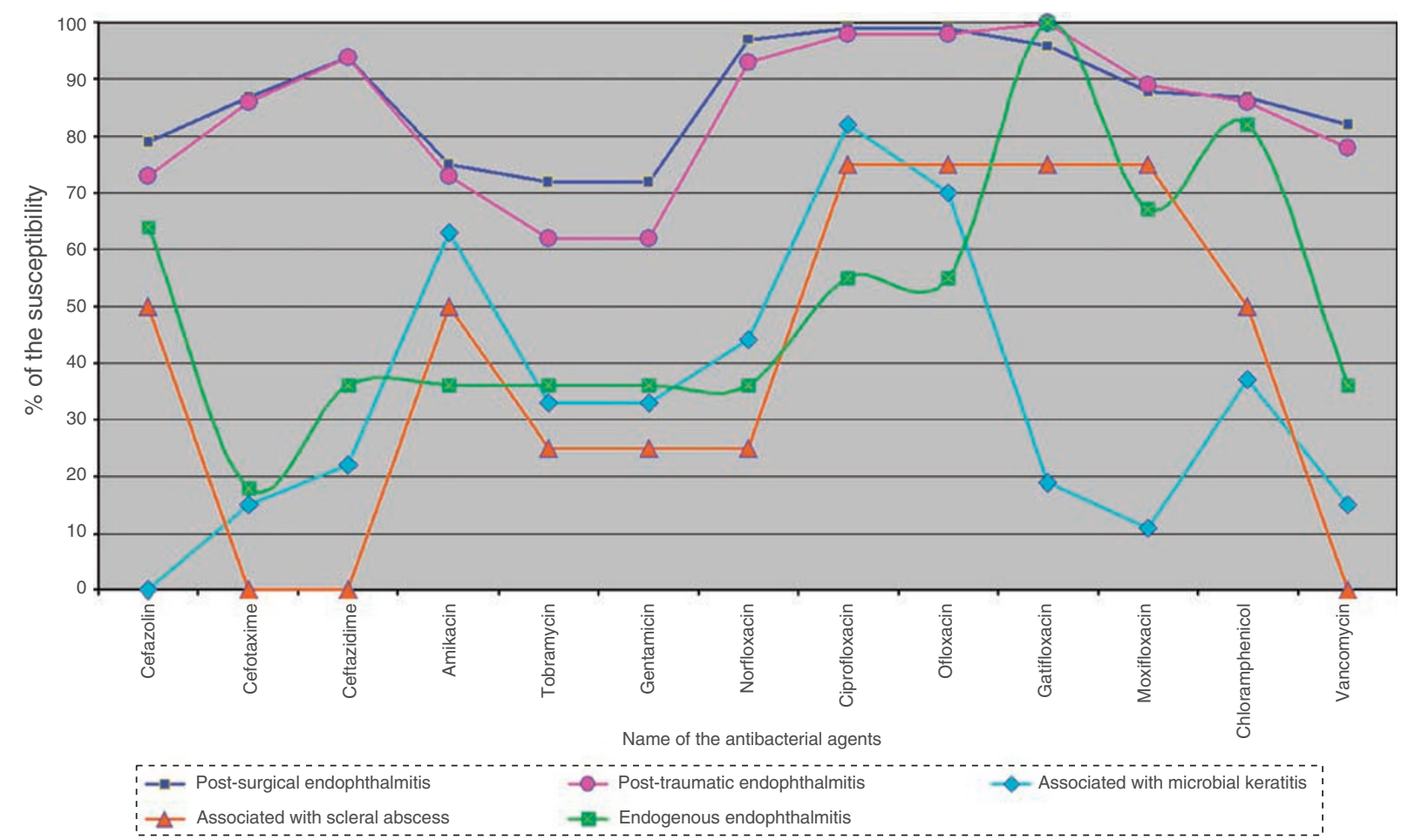

Figure 1 Diagrammatic representation of the comparative in vitro antibacterial susceptibilities of bacterial isolates recovered from eyes with endophthalmitis according to the clinical settings.

in vitro antibacterial susceptibility testing may not directly apply to ocular pathogens, as the results of disc diffusion susceptibility tests relate to the level of drug achievable in serum and do not relate directly to the concentration of drug produced in the pre-ocular tear film and ocular tissues by standard routes of administration. ${ }^{15}$ With this current study, we document the microbiological profile of infectious endophthalmitis; this will help in evidence-based management of endophthalmitis.

Disclosures: The submitted material has not been previously published and is not under consideration for publication elsewhere. The authors do not have any financial/conflict of interest linked with this submission. This submission is not an online only submission and it doesn't have any videos.

\section{References}

1 Forster RK. Endophthalmitis. In: Tasman W, Jaeger EA (eds). Duane's Clinical ophthalmology, external Diseases: Diseases of the Uvea, Volume 4, Chapter 24 Lippincott Company: Philadelphia: JB, 1994, pp 1-29.

2 Kresloff MS, Castellarin AA, Zarbin MA. Endophthalmitis. Surv Ophthalmol 1998; 43: 193-224.

3 Han DP, Wisniewski SR, Wilson LA, Barza M, Vine AK, Doft $\mathrm{BH}$ et al. Spectrum and susceptibilities of microbiologic isolates in the Endophthalmitis Vitrectomy Study. Am J Ophthalmol 1996; 122: 1-17.

4 Callegan MC, Engelbert M, Parke II DW, Jett BD, Gilmore MS. Bacterial endophthalmitis: epidemiology, therapeutics, and bacterium-host interactions. Clin Microbiol Rev 2002; 15: 111-124.

5 Jackson TL, Eykyn SJ, Graham EM, Standford MR. Endogenous bacterial endophthalmitis: a 17 year prospective series and review of 267 reported cases. Surv Ophthalmol 2003; 48: 403-424.

6 Das TP, Kunimoto DY, Sharma S, Jalali S, Majji AB, Rao TN et al. Relationship between clinical presentation and visual outcome in postoperative and posttraumatic endophthalmitis in south central India. Indian J Ophthalmol 2005; 53: 5-16.

7 Scott IU, Flynn HW, Feuer W, Pflugfelder SC, Alfonsa EC, Forster RK et al. Endophthalmitis associated with microbial keratitis. Ophthalmology 1996; 103: 1864-1870.

8 Puliafito CA, Baker AS, Haaf J, Foster S. Infectious endophthalmitis. Review of 36 cases. Ophthalmology 1982; 89: 921-929.

9 Okada AA, Johnson PR, liles WC. Endogenous bacterial endophthalmitis. Report of a ten-year retrospective study. Ophthalmology 1994; 101: 832-838.

10 Greenwald MJ, Wohl LG, Sell CH. Metastatic bacterial endophthalmitis. A contemporary reappraisal. Surv Ophthalmol 1986; 31: 81-101.

11 Endophthalmitis Vitrectomy Study Group. Microbiologic factors and visual outcome in the Endophthalmitis Vitrectomy Study. Am J ophthalmol 1996; 122: 830-846.

12 Speaker MG, Milch FA, Shah MK, Eisner W, Kreiswirth BN. Role of external bacterial flora in the pathogenesis of acute 
postoperative endophthalmitis. Ophthalmology 1991; 98 : 639-649.

13 Walker CB, Claoue CMP. Incidence of conjunctival colonization by bacteria capable of causing postoperative endophthalmitis. J R Soc Med 1986; 79: 520-521.

14 Wilhelmus KR, Liesegang TJ, Osato MS, Jones DB. Laboratory diagnosis of ocular infections. In: Specter SC (ed). CUMITECH. American Society for Microbiology: Washingdon DC, 1994, pp 18-20.

15 Byrne KA, Burd E, Tabbara K, Hyndiuk R (eds) Diagnostic Microbiology and Cytology of the Eye. Butterworth Heinemann: Boston, 1995.

16 Endophthalmitis Vitrectomy Study Group. Results of the Endophthalmitis Vitrectomy Study: a randomized trial of immediate vitrectomy and of intravenous antibiotics for the treatment of postoperative bacterial endophthalmitis. Arch Ophthalmol 1995; 113: 1479-1496.

17 Fahmy JA, Moller S, Bentzon MW. Bacterial flora in relation to cataract extraction. II. Preoperative flora. Acta Ophthalmology 1975; 53: 476-494.

18 Mayer E, Cadman D, Ewings P, Twomey JM, Gray RH, Claridge KG et al. A 10 year retrospective survey of cataract surgery and endophthalmitis in a single eye unit: injectable lenses lower the incidence of endophthalmitis. $\mathrm{Br} \mathrm{J}$ Ophthalmol 2003; 87: 867-869.

19 Johnson MW, Doft BH, Kelsey SF, Barza M, Wilson LA, Barr $\mathrm{CC}$ et al. Endophthalmitis Vitrectomy Study Group. Relationship beween clinical presentation and microbiologic spectrum. Ophthalmology 1997; 104: 261-272.

20 Lalitha P, Rajagopalan J, Prakash K, Ramasamy K, Prajna NV, Srinivasan M. Postcataract endophthalmitis in South India: incidence and outcome. Ophthalmology 2005; 12: 1885-1890

21 Eifrig CW, Flynn Jr HW, Scoot IU, Newton J. Acute-onset postoperative endophthalmitis: review of incidence and visual outcomes (1995-2001). Ophthalmic Surg Laser 2002; 33: 373-378.

22 Lertsumitkul S, Myers PC, O'Rourke MT, Chandra J. Endophthalmitis in the Western Syndeny region: a case control study. Clin Exp Ophthalmol 2001; 29: 400-405.

23 Montan PG, Kornayi G, Setterquist HE, Stridh A, Philipson BT, Wiklund K. Endophthalmitis after cataract surgery: risk factors relating to technique and events of the operation and patients history: a retrospective case control study. Ophthalmology 1998; 105: 2171-2177.

24 Anand AR, Therese KL, Madhavan HN. Spectrum of aetiological agents of postoperative endophthalmitis and antibiotic susceptibility of bacterial isolates. Indian J Ophthalmol 2000; 48: 123-128.

25 Irvine WD, Flynn Jr HW, Miller D, Pflugfelder SC. Endophthalmitis caused by gram negative organisms. Arch ophthalmitis 1992; 110: 1450-1454.

26 Driebe Jr WT, Mandelbaum S, Forster RK, Schwartz LK, Culbertson WW. Pseudophakic endophthalmitis: diagnosis and management. Ophthalmology 1986; 93: 442-448.

27 Fox GM, Joondeph BC, Flynn Jr HW, Pflugfelder SC, Roussel TJ. Delayed onset pseudophakic endophthalmitis. Am J ophthalmol 1983; 90: 692-699.

28 Pflugfelder SC, Flynn HW, Zwickey TA, Forster RK, Tsiligianni A, Culbertson WW. Exogenous fungal endophthalmitis. Ophthalmology 1988; 95: 19-30.

29 Boldt HC, Pulido JS, Blodi CF, Folk JC, Weingeist TA. Rural endophthalmitis. Ophthalmology 1989; 96: 1722-1726.

30 Thomas PA. Current perspectives on ophthalmic mycoses. Clin Microbiol Rev 2003; 16: 730-797.

31 Jackson WB. Infection of the sclera. In: Tabbara KF, Hyndiuk RA (eds). Infections of the Eye, 2nd edn. Little, Brown and Company: Boston, 1996 pp 487-497.

32 Wong JS, Chan TK, Lee HM, Chee SP. Endogenous bacterial endophthalmitis: an East Asian experience and a reappraisal of a severe ocular affliction. Ophthalmology 2000; 107: 1483.

33 Reedy JS, Wood KE. Endogenous Pseudomonas aeruginosa endophthalmitis: a case report and literature review. Intensive Care Med 2000; 26: 1386-1389.

34 Kowalski RP, Karenchak LM, Romanowski EG. Infectious disease: changing antibiotic susceptibility. Ophthalmol Clin N Am 2003; 16: 1-9.

35 Gaynor BD, Chidambaram JD, Cevallos V, Miao Y, Miller K, Jha HC et al. Topical ocular antibiotics induce bacterial resistance at extraocular sites. $\mathrm{Br} J$ Ophthalmol 2005; 89: 1097-1099. 